\title{
IDENTIFIKASI TINGKAT KECEMASAN PRE OPERASI PASIEN FRAKTUR DI RUANG ASTER DAN CEMPAKA RSUD ABDUL WAHAB SJAHRANIE SAMARINDA
}

\author{
Diah Setiani \\ Prodi Diploma III Keperawatan Jurusan Keperawatan \\ Politeknik Kementerian Kesehatan Kalimantan Timur \\ diah.dee.oc@gmail.com
}

\begin{abstract}
ABSTRAK
Di Indonesia, mobilitas yang tinggi dan faktor kelalaian manusia menjadi salah satu penyebab terjadinya kecelakaan lalu lintas. Dari jumlah total peristiwa kecelakaan yang terjadi, terdapat 5,8\% korban cedera atau sekitar delapan juta orang yang mengalami fraktur dengan jenis fraktur yang paling banyak terjadi yaitu fraktur pada bagian ekstremitas atas sebesar 36,9\% dan ekstremitas bawah sebesar 65,2\% (Departemen Kesehatan Republik Indonesia, 2013). Ketika seseorang mengalami fraktur ekstremitas, upaya untuk mengembalikan struktur dan fungsi tulang menjadi normal kembali salah satunya adalah dengan melakukan pembedahan. Berdasarkan data rekam medik RSUD Abdul Wahab Sjahranie Samarinda pada tahun 2016, jumlah pasien yang mengalami bedah ortopedi sebanyak 1.579 jiwa. Menurut Smeltzer dan Bare (2002) tindakan operasi atau pembedahan merupakan pengalaman yang bisa menimbulkan kecemasan. Menurut Carpenito (2002) $90 \%$ pasien pre operasi berpotensi mengalami kecemasan. Dalam menentukan tingkat kecemasan tersebut diperlukan instrumen pengkajian yang sudah teruji validitas dan reabilitasnya yaitu dengan menggunakan Hamillton Anxiety Rating Scale (HARS). Tujuan penelitian: Mengetahui gambaran tingkat kecemasan pada pasien pre operasi pasien yang mengalami fraktur. Metode: Penelitian deskriptif dengan metode pendekatan cross sectional study. Teknik pengambilan sampel menggunakan metode accidental sampling didapatkan responden sebanyak 17 orang pada bulan Mei s/d Juli 2017 di Ruang Aster dan Cempaka RSUD Abdul Wahab Sjahranie Samarinda. Hasil: berdasarkan hasil analisis univariat, sebagian kecil mengalami $2(11,8 \%)$ tidak cemas dan $5(29,4 \%)$ mengalami cemas ringan, sedangkan sebagian besar 10 (58,8\%) responden mengalami kecemasan sedang. Kesimpulan: tingkat kecemasan pada pasien pre operasi pasien yang mengalami fraktur sebagian besar $10(58,8 \%)$ responden mengalami kecemasan sedang.
\end{abstract}

Kata Kunci : cemas, pasien fraktur, pre operasi

\section{ABSTRACT}

Background: In Indonesia, High mobility and human careless become one of the factors of traffic accident. The total number of traffic accident that occured, there were $5.8 \%$ injures or about eight million people was suffering form fractures with the most common fracture type that often occurs, that was $36.9 \%$ limb fractures in the upper extremity and 65,2\% limb fracture in lower extremity (Departemen Kesehatan Republik Indonesia, 2013). When people had limb fracture, surgery become one of efforts to restore the structure and the function of the bones into the initial condition. According to the medical data record of Abdul Wahab Sjahranie Hospital Samarinda in 2016, The number of patient who had ortopedic surgery was about 1.579 people. Smeltzer and Bare (2002) stated that Surgery is something that can cause the anxiety. Accordng to Carpenito (2002) 90\% prasurgery patient potentially had anxiety. In determining the level of that anxiety, it is necessary to have valid dan realiable asessment instrument that has been tested by using Hamillton Anxiety Rating Scale (HARS). Purpose of study: To know descreption level anxienty patient of pra surgery on fracture patient. Method : research description to approach methode cross sectional study. Technique taking sample to this reasearch is using accidental sampling methode obtained respondent as much 17 person in mei until july 2017 at aster room and cempaka room of RSUD Abdul Wahab Sjahranie Samarinda. Result : based on univariat analysis, fraction have $2(11,8 \%)$ not anxiety and $5(29,4 \%)$ have mild anxiety, while most of the $10(58,8 \%)$ respondent have 
moderate anxiety.Conclusion : level anxiety on patient pre surgery who have fractur, most of the 10 $(58,8 \%)$ respondet have moderate anxiety.

Keywords : anxiety, fracture patient, pra-surgery

\section{PENDAHULUAN}

Kecelakaan lalu lintas merupakan kejadian yang sering menjadi berita utama di berbagai media. Di Indonesia, mobilitas yang tinggi dan faktor kelalaian manusia menjadi salah satu penyebab terjadinya kecelakaan lalu lintas. Menurut data kepolisian RI tahun 2012, terjadi 109.038 kasus kecelakaan lalu lintas di seluruh Indonesia, sedangkan menurut data badan kesehatan dunia (WHO) tahun 2011, kecelakaan lalu lintas di Indonesia dinilai menjadi pembunuh ketiga setelah penyakit jantung koroner dan tuberculosis. Kecelakaan lalu lintas di Indonesia setiap tahunnya meningkat. Terdapat peningkatan $21,8 \%$ dalam jangka waktu lima tahun. Dari jumlah total peristiwa kecelakaan yang terjadi, terdapat $5,8 \%$ korban cedera atau sekitar delapan juta orang yang mengalami fraktur dengan jenis fraktur yang paling banyak terjadi yaitu fraktur pada bagian ekstremitas atas sebesar 36,9\% dan ekstremitas bawah sebesar 65,2\% (Departemen Kesehatan Republik Indonesia, 2013). Ketika seseorang mengalami fraktur ekstremitas, upaya untuk mengembalikan struktur dan fungsi tulang menjadi normal kembali salah satunya adalah dengan melakukan pembedahan.

Operasi atau pembedahan adalah suatu penanganan medis secara invasive yang dilakukan untuk mendiagnosa atau mengobati penyakit, injuri, atau deformitas tubuh (Nainggolan, 2013). Kiik (2013) menyatakan bahwa tindakan pembedahan akan mencederai jaringan yang dapat menimbulkan perubahan fisiologis tubuh dan mempengaruhi organ tubuh lainnya. Berdasarkan data yang diperoleh dari World Health Organization (WHO) dalam Sartika (2013), jumlah pasien dengan tindakan operasi mencapai angka peningkatan yang sangat signifikan dari tahun ke tahun. Tercatat ditahun 2011 terdapat 140 juta pasien di seluruh rumah sakit di dunia, sedangkan pada tahun 2012 data mengalami peningkatan sebesar 148 juta jiwa. Berdasarkan data rekam medik RSUD Abdul Wahab Sjahranie Samarinda pada tahun 2016, jumlah pasien yang mengalami bedah ortopedi sebanyak 1.579 jiwa. Menurut Smeltzer dan Bare (2002) tindakan operasi atau pembedahan merupakan pengalaman yang bisa menimbulkan kecemasan. Kecemasan biasanya berhubungan dengan segala macam prosedur asing yang harus di jalani pasien dan juga ancaman terhadap keselamatan jiwa akibat prosedur pembedahan dan tindakan pembiusan. Pasien yang mengalami kecemasan menunjukkan gejala mudah tersinggung, susah tidur, gelisah, lesu, mudah menangis dan tidur tidak nyenyak. Menurut Carpenito (2002) 90\% pasien pre operasi berpotensi mengalami kecemasan.

Kecemasan (ansietas) adalah respon psikologik terhadap stress yang mengandung komponen fisiologik dan psikologik. Reaksi fisiologis terhadap kecemasan merupakan reaksi yang pertama timbul pada sistem saraf otonom, meliputi peningkatan frekuensi nadi dan respirasi, pergeseran tekanan darah dan suhu, relaksasi otot polos pada kandung kemih dan usus, kulit dingin dan lembab. Manifestasi yang khas pada pasien pre operasi tergantung pada setiap individu dan dapat meliputi menarik diri, membisu, mengumpat, mengeluh dan menangis. Respon psikologis secara umum berhubungan adanya kecemasan menghadapi anestesi, diagnosa penyakit yang belum pasti, keganasan, nyeri, ketidaktahuan tentang prosedur operasi dan sebagainya. Kecemasan pasien pre operasi disebabkan berbagai faktor, salah satunya adalah faktor pengetahuan dan sikap perawat dalam mengaplikasikan pencegahan kecemasan pada pasien pre operasi. Kecemasan berhubungan dengan segala macam prosedur asing yang harus dijalani pasien dan juga ancaman terhadap keselamatan jiwa akibat prosedur pembedahan dan tindakan pembiusan. Keperawatan pre operatif merupakan tahapan awal dari keperawatan perioperatif. Hal ini disebabkan fase ini merupakan awal yang menjadi landasan untuk kesuksesan tahapan-tahapan berikutnya. Pengkajian secara integral dari fungsi pasien meliputi fungsi fisik biologis dan psikologis sangat diperlukan untuk keberhasilan dan kesuksesan suatu operasi.

Perawat mempunyai peranan yang sangat penting dalam setiap tindakan pembedahan baik pada masa sebelum, selama maupun setelah operasi. Intervensi keperawatan yang tepat diperlukan untuk mengurangi tingkat kecemasan klien dengan memberikan informasi - informasi akurat yang 
dibutuhkan oleh pasien sesuai dengan kondisi dan tingkat kecemasan yang dialaminya. Setiap orang mempunyai mekanisme koping yang berbeda, sehingga sebelum pemberian intervensi perlu diadakan pengkajian untuk mengetahui tingkat kecemasan yang dialami pasien. Dalam menentukan tingkat kecemasan tersebut diperlukan instrumen pengkajian yang sudah teruji validitas dan reabilitasnya yaitu dengan menggunakan Hamillton Anxiety Rating Scale (HARS).

\section{TUJUAN} fraktur

Mengetahui gambaran tingkat kecemasan pada pasien pre operasi pasien yang mengalami

\section{METODE}

Penelitian deskriptif dengan metode pendekatan cross sectional study. Lokasi penelitian dilaksanakan di Ruang Aster dan Cempaka RSUD Abdul Wahab Sjahranie Samarinda. Populasi pada penelitian ini adalah semua pasien fraktur yang akan menjalani operasi di RSUD AWS Samarinda pada bulan Mei s/d Juli 2017. Dengan teknik pengambilan accidental sampling. Pasien yang dapat ditetapkan sebagai sampel dalam penelitian ini harus memenuhi kriteria inklusi.

a. Kriteria inklusi dalam penelitian ini adalah :
1) Pasien pre operasi
2) Usia minimal 14 Tahun
3) Bisa membaca dan menulis
4) Bersedia untuk di teliti
5) Bersedia menjadi responden

b. Kriteria eksklusi, yang akan digunakan untuk mengeliminasi responden yang memenuhi kriteria inklusi dalam penelitian ini adalah Pasien pre operasi yang mengalami penurunan kesadaran.

HASIL

\section{Tabel Distribusi Frekuensi Tingkat Kecemasan Responden}

\begin{tabular}{lccccc}
\hline $\begin{array}{c}\text { Tingkat } \\
\text { kecemasan }\end{array}$ & n & $\mathbf{( \% )}$ & $\begin{array}{c}\text { Min- } \\
\text { maks }\end{array}$ & Mean & Sd \\
\hline Tidak cemas & 2 & 11,8 & $1-3$ & 2,47 & 0,717 \\
Cemas ringan & 5 & 29,4 & & & \\
Cemas sedang & 10 & 58,8 & & & \\
\hline
\end{tabular}

Berdasarkan tabel 4.2 menunjukkan bahwa hasil analisis univariat, sebagian kecil mengalami $2(11,8 \%)$ tidak cemas dan $5(29,4 \%)$ mengalami cemas ringan, sedangkan sebagian besar $10(58,8 \%)$ responden mengalami kecemasan sedang.

\section{PEMBAHASAN}

Hasil penelitian menunjukkan bahwa, sebagian besar $10(58,8 \%)$ responden mengalami kecemasan sedang. Hal ini menunjukkan tindakan operasi yang akan dihadapi dalam penanganan fraktur bagi pasien menimbulkan kecemasan, teridentifikasi dengan pengkajian kecemasan menggunakan instrument HARS.

Menurut teori, kecemasan adalah ketegangan atau perasaan tidak aman dan dikuatirkan yang timbul karena dirasa akan terjadi sesuatu hal yang tidak menyenangkan, tetapi gambarannya sebagaian besar tidak diketahui (Maramis, 2005). Cemas adalah rasa takut terhadap sesuatu yang tidak kita ketahui atau rasa takut pada apa yang akan terjadi. Cemas ini bersifat samar, tidak menyenangkan, dan disertai gejala fisik (Kandouw, 2006). Tanda-tanda yang sering muncul pada responden diantaranya sering bangun pada malam hari, denyut nadi meningkat, gemetar, merasa takut terhadap ruang operasi, peralatan dan takut operasinya gagal. Hal ini dikarenakan respon cemas seseorang tergantung pada kematangan pribadi, pemahaman dalam menghadapi tantangan harga diri dan mekanisme koping yang digunakan dalam menghadapi cemas. Kecemasan tersebut muncul karena adanya faktor predisposisi dan presipitasi. Faktor predisposisi menurut Freud dan 
Corey (2005) dibagi menjadi lima yaitu: adanya konflik emosional, perasaan takut, frustasi, peran keluarga, biologis. Faktor presipitasi dikelompokkan menjadi 2 kategori yaitu: ancaman ketidakmampuan fisiologis dan sistem diri seseorang. Dengan adanya tindakan pada pasien pre operasi yang mengalami fraktur, hal tersebut sudah termasuk dalam faktor predisposisi dan presipitasi sehingga menimbulkan suatu kecemasan

Hasil penelitian terdahulu, Nyi Dewi Kuraesin (2009) menunjukkan tingkat kecemasan sebagian besar $31(67,4 \%)$ pasien yang akan menjalani operasi mayor elektif Di Ruang Rawat Bedah Rsup Fatmawati-Jakarta Selatan, dalam kategori kecemasan ringan. Kemudian dalam hasil penelitian Yanti, dkk (2015) menunjukkan bahwa sebagian besar $16(38,1 \%)$ pasien pre operasi SC di Ruang Kebidanan RS Urip Sumoharjo Bandar Lampung mengalami kecemasan ringan. Walaupun tidak sejalan dengan hasil penelitian terdahulu, bila pasien akan menjalani suatu tindakan invasif berupa operasi maka akan menimbulkan suatu kecemasan.

Asumsi peneliti, berdasarkan hasil penelitian tingkat kecemasan yang dirasakan pasien pre operasi yang mengalami fraktur adalah kecemasan sedang. Menimbulkan suatu respon fisiologis dan emosional. Respon fisiologis yang muncul diantaranya : beberapa gejala yang tidak normal bisa ditemukan, persepsi pandangan menyempit, respon muncul secara langsung (dapat merespon terhadap perintah), masih dapat memecahkan masalah secara efektif dan merespon dapat langsung dan perlu support, perhatian selektif dan berfokus pada rangsangan yang tidak menambah kecemasan. Kemudian respon emosional / tingkah laku yang muncul diantaranya: tidak sabar, mudah tersinggung, mudah lupa, banyak pertimbangan, menangis dan marah, menggunakan beberapa macam mekanisme koping.

\section{KESIMPULAN}

Berdasarkan hasil penelitian identifikasi tingkat kecemasan pre operasi pada pasien fraktur di Ruang Aster dan Cempaka RSUD Abdul Wahab Sjahranie, maka dapat disimpulkan: tingkat kecemasan responden menunjukkan bahwa, sebagian besar $10(58,8 \%)$ responden mengalami kecemasan sedang.

\section{SARAN}

1. Bagi Perawat Ruang Aster dan Cempaka RSUD AWS Samarinda Kalimantan Timur

Dapat memberikan tindakan keperawatan yang bertujuan dalam mengatasi kecemasan yang dialami pasien, khususnya pada pasien yang akan menjalani tindakan operasi. Sehingga komplikasi akibat cemas dapat diminimalisir atau dihilangkan.

2. Bagi pasien dan keluarga

Sebelum pasien akan menjalani tindakan operasi dapat memberikan informasi bila merasakan tanda-tanda kecemasan yang dialami kepada perawat/ pemberi layanan kesehatan agar komplikasi akibat kecemasan tidak terjadi yang mempengaruhi dalam pemberian tindakan medis.

3. Bagi Peneliti Selanjutnya

Hasil penelitian dari identifikasi tingkat kecemasan sebelum operasi pada pasien fraktur dapat dilanjutkan menjadi data dasar untuk menerapkan tindakan keperawatan dalam mengatasi dan mengurangi kecemasan. Selain itu diharapkan identifikasi tingkat kecemasan sebelum operasi diterapkan pada responden yang sama dalam jenis tindakan operasi dan menambah jumlah respondennya.

\section{KEPUSTAKAAN}

Arikunto, S. 2005. Manajemen Penelitian. Jakarta : Rineka Cipta.

Asmadi. 2005. Konsep Dasar Keperawatan. Jakarta : EGC.

Davison, G.C., Neale, J.M. 2006. Psikologi Abnormal. Jakarta : PT. Raja Grafindo Persada.

Departemen Kesehatan Republik Indonesia. 2013. Riskesdas 2013 dalam Angka. Kementerian Kesehatan Republik Indonesia. Jakarta.

Gibson, John. 2003. Fisiologi Dan Anatomi Modern Untuk Perawat. Jakarta : EGC.

Hasan, M.I. 2002. Pokok-Pokok Materi Metodologi Penelitian Dan Aplikasinya. Jakarta : Gralia Indonesia. 
Hawari, D. 2006. Buku Saku Keperawatan Jiwa. Jakarta : EGC

Hidayat, A. Aziz Alimul. 2008. Riset Keperawatan Dan Teknik Penulisan Ilmiah . Jakarta : Salemba Medika

Kusuma, H., Nurarif, A.H. 2012. Aplikasi Asuhan Keperawatan Berdasarkan NANDA NIC-NOC. Yogyakarta : Media Hardy

Nursalam. 2008. Konsep Dan Penerapan Metodologi Penelitian Ilmu Keperawatan. Jakarta Selatan : Salemba Medika

Kuraesin, Nyi Dewi. 2009. Faktor-Faktor Yang Berhubungan Dengan Tingkat Kecemasan Pasien Yang Akan Menjalani Operasi Mayor Elektif Di Ruang Rawat Bedah Rsup FatmawatiJakarta Selatan. FIK UIN Syarif Hidayatullah Jakarta

Price, Sylvia Anderson. 2005. Patofisiologi : konsep klinis proses-proses penyakit. Jakarta : EGC

Setiadi. 2012. Konsep Dan Praktik Penulisan Riset Keperawatan. Surabaya : Graha Ilmu

Smeltzer, S.C., Bare, B.G. 2002. Buku Ajar Keperawatan Medikal Bedah. Vol.2. Ed.8. Jakarta : EGC

Sugiyono. 2010 . Statistik Untuk Penelitian. Bandung : Alfabeta.

Sumadinata, N.S. (2005). Metode Penelitian Pendidikan. Bandung : PT. Remaja Resda Karya.

Yanti, Desi Ari M., dkk. 2016. Hubungan Pendidikan Dengan Kecemasan Pasien Pre Operasi Seksio Sesaria (Sc) Di Ruang Kebidanan Rumah Sakit Urip Sumoharjo Bandar Lampung Tahun 2015 . Jurnal Asuhan Ibu \& Anak (JAIA) 2016: 1 (2): 35-41. 